DOI: 10.34015/2523-4552.2021.1.07

УдК 343.8

Колб Р. O., аспірант кафедри кримінального права і процесу Волинського національного університету імені Лесі Українки ORCID: 0000-0003-0187-3391

\title{
ПРО РОЛЬ І МІСЦЕ НАЦІОНАЛЬНОГО БАНКУ УКРАЇНИ У СИСТЕМІ СУБ'ЄКТІВ ЗАПОБІГАННЯ КРИМІНАЛЬНИМ ПРАВОПОРУШЕННЯМ
}

У даній науковій статті з'ясовано сутність і соціально-правову природу Національного банку України у системі суб’єктів запобігання кримінальним правопорушенням, а також визначено його роль та розроблено науково обгрунтовані заходи, спрямовані на підвищення рівня ефективності зазначеної діяльності.

Ключові слова: Національний банк України; запобігання; кримінальне правопорушення; сфера банківської діяльності; шахрайство з фінансовими ресурсами; завдана шкода; збитки.

В данной научной статье выяснено сущность и социально-правовую природу Национального банка Украины в системе субъектов предупреждения уголовным правонарушениям, а также определены его роль и разработаны научно обоснованные мероприятия, направленные на повышение уровня эффективности указанной деятельности.

Ключевые слова: Национальный банк Украины; предупреждения; уголовное преступление; сфера банковской деятельности; мошенничество с финансовыми ресурсами; причиненный вред; убытки.

Постановка проблеми. Як свідчить практика, одним із самих суспільно небезпечних кримінальних правопорушень, які вчиняються у сфері господарської діяльності, $\epsilon$ ті із них, що посягають на встановлений на нормативно-правовому рівні порядок діяльності банківських установ України (до таких, зокрема, можна віднести наступні із них: ст. 209 «Легалізація (відмивання) доходів, одержаних злочинним шляхом»; ст. 209-1 «Умисне порушення вимог законодавства про за- побігання та протидію легалізації (відмивання) доходів, одержаних злочинним шляхом або фінансування тероризму»; ст. 218-1 «Доведення банку до неплатоспроможності» Кримінального кодексу (КК) України та ін.). Так, розпочинаючи 32016 року, в Україні намітилась негативна тенденція до щорічного збільшення кількості зареєстрованих у Єдиному реєстрі досудового розслідування (у середньому до 500 випадків) кримінальних правопорушень, що мають місце у 
зазначеній сфері суспільних відносин [1].

Не покращились та суттєво не змінились ці показники й у подальші роки (2017-2020 рр.). Так, за даними Національної поліції тільки у 2019 році в Україні відкрили 4 тис. 263 кіберзлочини, у тому числі й у сфері банківських установ, які завдали збитків на 28 млн. гривень [2].

Показовою у цьому контексті $\epsilon$ протиправна діяльність банку «Аркада», у результаті якої були незаконно виведені 3 його фінансового обігу 9 млрд. грн., а також зменшено норматив коефіцієнта покриття ліквідністю за всіма валютами (LCR) із $100 \%$ до $60,23 \%$ [3].

Отже, слід визнати, що в наявності складна прикладна проблема, яка потребує вирішення, у тому числі й на теоретичному рівні. При цьому варто зазначити, що однією з умов, яка сприяє вчиненню кримінальних правопорушень у функціонування банківських установ, $є$ неналежна діяльність Національного банку України (НБУ) по їх запобіганню, як це передбачено п. 30 ч. 1 ст. 7 Закону України «Про Національний банк України» [4].

Постановка завдання. Метою наукової статті $\epsilon$ з'ясування ролі та місця Національного банку України (НБУ) у системі суб'єктів запобігання кримінальним правопорушенням, а головним завданням - розробка науково обгрунтованих заходів, спрямованих на удосконалення правових засад запобіжної діяльності зазначеного банку у сфері боротьби зі злочинністю.

Аналіз останніх досліджень і публікацій. Вивчення наукових джерел показало, що досить активно та продуктивно питаннями підви- щення ефективності запобігання кримінальним правопорушенням різними суб'єктами займаються як кримінологи, так і інші науковці, зокрема у сфері банківської діяльності, а саме: К. А. Абрамов, В. В. Василевич, М. І. Глотов, В. В. Голіна, Б. М. Головкін, О. М. Джужа, В. М. Некрасов, O. I. Олійничук, I. М. Осика, С. О. Пиріг, С. В. Поперешняк, Т. В. Романенко, С. В. Самойлов, С. С. Шапочка, В. І. Шакун та ін. Поряд 3 цим, проблеми, які склали зміст предмета дослідження у даній науковій статті, комплексному аналізу у доктринальній літературі досі не досліджувались, що й обумовило їі актуальність, теоретичне та практичне значення.

Виклад основних положень. Відповідно до вимог ст. 2 Закону України «Про Національний банк України», НБУ є центральним банком України, особливим центральним органом державного управління, юридичний статус, завдання, функції, повноваження і принципи організації якого визначаються Конституцією України, цим Законом та іншими законами України. При цьому основною функцією НБУ, як це зазначено в ч. 1 ст. 6 даного Закону, $\epsilon$ забезпечення стабільності грошової одиниці України.

Для іï реалізації та створення реальних гарантій виконання у повному об'ємі своїх повноважень законодавець визначив перелік й інших функцій НБУ (ст. 7 Закону України «Про Національний банк України»). Їх аналіз дозволяє стверджувати, що при такому дуалістичному підході НБУ зобов'язана належним чином вживати всі передбачені законом заходи щодо запобігання посяганням як на стабільність фінансової системи, так і на встановлений порядок 
протидії легалізації (відмиванню) коштів, здобутих злочинним шляхом, особливо після внесення суттєвих змін і доповнень у Закон України «Про Національний банк України»в період 2014-2021 рр.

Поряд 3 цим, як встановлено в ході даного дослідження, реальність $€$ дещо іншою. Як 3 цього приводу у свій час влучно зауважив Р. Шпек, діючий КК України місить певні норми, які, при правильному їх використанні, могли б посилити корпоративну безпеку та належний захист прав банківських установ у кримінальному судочинстві [1]. У той самий час, практика свідчить про те, що ці норми не працюють належним чином. Зокрема, особливу занепокоєність у зв'язку з цим викликають випадки кредитного шахрайства у процесі повернення кредитів відповідним банківським установам. При цьому найпоширенішими видами кримінальних правопорушень $є$ : шахрайство (ст. 190 КК), шахрайство з фінансовим ресурсами (ст. 222 КК), підробка документів, що пов'язана 3 цими проявами шахрайства (ст. 358 КК), незаконні дії із заставним майном (ст. 388 КК) та умисне невиконання або перешкоджання виконанню судових рішень (ст. 382 КК); ін. [1].

Все це свідчить про те, що НБУ неналежним чином виконує свої зобов'язання щодо організації запобіжної діяльності у системі банківських установ, що визначені в ст. 7 Закону України «Про Національний банк України». Мова, у тому числі, ведеться й про налагодження ефективності взаємодії з означених питань 3 правоохоронними органами, у першу чергу, з новоствореним Бюро економічної безпеки (БЕБ) [5]. Зокрема, як свідчить практика, щорічно лише 1\% заяв банківських установ про вчинені у сфері їх діяльності кримінальні правопорушення правоохоронцями доведено до суду [1]. Як у зв'язку з цим слушно резюмують фахівці банківської справи, на жаль, ситуація яка зараз спостерігається по розкриттю злочинів у банківській сфері, не говорить про ефективність роботи банків та правоохоронних органів [1].

Як видається, логічним у зв'язку з цим було б доповнення ч. 1 ст. 7 Закону України «Про Національний банк України» п. наступного змісту:

«Для забезпечення ефективності реалізації визначених у цій статті Закону інших функцій Національного банку України останній зобов'язаний налагодити належну взаємодію з правоохоронними органами, особливо з питань запобігання вчиненню у сфері банківської діяльності кримінальних правопорушень».

Додатковим аргументом щодо запропонованої видозміни виступають науково обгрунтовані висновки науковців про те, що зволікання та службова недбалість у даному напрямі завдає значні збитки для стабільності фінансової системи держави (a, це - пріоритетне завдання НБУ (ст. 6 Закону України «Про Національний банк України»)), а також завдає значної шкоди для різних суб'єктів господарської діяльності, включаючи й іноземців [6, с. 94].

Без сумніву, що важливим у цьому сенсі $\epsilon$ й впровадження $\mathrm{y}$ національне банківське законодавство та практику позитивного зарубіжного досвіду, що стосується змісту запобігання кримінальним правопорушенням у зазначеній сфері 
суспільних відносин. Так, для протидії суспільно небезпечним явищам, що пов'язане 3 картковим шахрайством, оператори міжнародних платіжних систем розробили новий стандарт платіжних карток EMV (технологія «ЧІП» та «ПІН»), а також різні додатки безпеки, зокрема, додаток 3D Secure для операцій онлайн, які, як показує практика, складніше клонувати [7].

Отже, в цьому напрямі НБУ має активізувати свої зусилля, враховуючи, що питання впровадження кращих практик і стандартів, які існують у міжнародній банківській діяльності, відносяться до одних (інших) із функцій даного банку (п. п. 13, 21, 30 ст. 7 Закону України «Про Національний банк України»).

Поряд з цим, слід визнати, що НБУ вже здійснив ряд запобіжних заходів, основу яких склали міжнародно-правові акти та позитивна зарубіжна практика такої діяльності у сфері функціонування банківських установ. До таких, наприклад, можна віднести наступні із них:

1) Положення про застосування Національним банком України заходів впливу, у якому визначено підстави і порядок застосування НБУ цих заходів і фінансових санкцій за порушення банками, філіями іноземних банків та іншими особами законодавства у сфері запобігання та протидії легалізацію (відмиванню) доходів, одержаних злочинним шляхом [8], що важливо 3 огляду реалізації змісту спеціальнокримінологічного запобігання кримінальним правопорушенням та у зв'язку з необхідністю підвищення ефективності взаємодії банківської системи і правоохоронних органів;
2) Положення про здійснення банками фінансового моніторингу, відповідно до якого банки вживають до клієнтів, з якими ділові відносини встановлюються 3 дати набрання чинності Закону України «Про запобігання та протидію легалізації (відмивання) доходів, одержаних злочинним шляхом, фінансуванню тероризму та фінансуванню розповсюдженню зброї масового знищення», необхідних заходів відповідно до вимог Закону [9], що також можна віднести до спеціальнокримінологічного запобігання кримінальним правопорушенням, яке у тому числі здійснює у виді інших функцій (ст. 7 Закону України «Про Національний банк України») НБУ;

3) інші запобіжні заходи, організовуються та реалізуються в банківській системі відповідними підрозділами НБУ (інформаційна компанія «Шахрай Гудбай», спрямована на вивчення населенням правил платіжної безпеки; спільна 3 Агенством CША «USAID» антишахрайська онлайн-гра «Здолай шахрая», метою якої $\epsilon$ розвиток і покращення власних навичок кібербезпеки, запобігання незаконному копіюванню вмісту треків смуги (чипів) банківських карток; ін.) [10].

Висновки. Таким чином, враховуючи результати проведеного аналізу наукової літератури, нормативно-правових джерел та практики, можна констатувати, що роль і місце НБУ у системі суб'єктів запобігання кримінальним правопорушенням обумовлені дуалістичною (подвійною) $[11$, с. 200] соціально-правовою природою даного особливого державного органу, який, з одного боку, основною функцією має забезпечення стабільності грошової одиниці 
України, а з іншого, - здійснювати комплекс інших функцій, спрямованих у тому числі на запобігання вчиненню кримінальних правопорушень у банківській системі. При цьому слід зазначити, що у другому напрямі своєї діяльності НБУ виступає як суб'єкт спеціально-кримінологічного запобігання кримінальним правопорушенням, позаяк ії зміст включає не тільки заходи агітаційно-заохочу- вальні, загальні запобіжні компанії тощо, що, зокрема, характерні для суб'єктів загальносоціального запобігання злочинам, але й зобов'язана (i це $є$ головним критерієм класифікації) здійснювати заходи примусового характеру, що має пряме відношення до діяльності саме суб'єктів спеціально-кримінологічного запобігання кримінальним правопорушенням.

\section{Список використаних джерел}

1. Шпек Р. Проблеми розкриття злочинів у банківській сфері. Інтернет-портал FinPost. URL: http://finpost.com.ua/news/5429 (дата звернення: 04.01.2021).

2. Анатомія кіберзлочину: ключові тренди 2020 року. Експертний центр з прав людини. URL: https://ecpl.com.ua/news/anatomiia-kiber-zlochynu (дата звернення: 04.01.2021).

3. Відкрито справу щодо 9 млрд. грн., зібраних через банк «Аркада». Фінансовый клуб. URL: https://finclub.net/ua/news/vidkryto-spravu-shchodo-9-mlrd-hrn-zibranykhcherez-bank-arkada.html (дата звернення: 04.01.2021)

4. Про Національний банк України: Закон України від 20 травня 1999 року № 679-XIV. Відомості Верховної Ради України. 1999. № 29. Ст. 238.

5. Про бюро економічної безпеки України: Закон України від 28.01.2021 p. № 1150-20. Офіційний вісник України. 2021. №25. Ст. 1151.

6. Олійничук О. Банківські картки як об'єкт шахрайства: стан і протидія явищу. Актуальні проблеми правознавства. 2017. Вип. 1(9). С. 91-94.

7. Глотов М. Як захистити свої гроші на картці. Інтернет-видання «Українська правда». URL: https://www.epravda.com.ua/columns/2015/07/8/549843/_(дата звернення: 04.01.2021).

8. Про затвердження Положення про застосування Національним банком України заходів впливу: постанова Правління Національного банку України від 17.08.2012. №346. Обіційний вісник України. № 72. Ст. 2906.

9. Про затвердження Положення про здійснення банками фінансового моніторингу: постанова Правління Національного банку України від 19.05.2020 р. № 65. Офіційний вісник України. № 62. Ст.1920.

10. Що робить НБУ для боротьби з шахрайством. Інтернет-портал FinPost. URL: http://finpost.com.ua (дата звернення: 04.01.2021).

11. Великий тлумачний словник сучасної української мови / укл. О. Єрмоленко. Донецьк: ТОВ «Глорія Трейд», 2012. 864 с.

\section{References}

Shpek, R. Problemy rozkryttia zlochyniv u bankivskii sferi. Internet-portal FinPost. URL: http://finpost.com.ua/news/5429 (data zvernennya: 04.01.2021).

Oliinychuk, O. (2017). Bankivski kartky yak ob'iekt shakhraistva: stan i protydiia yavyshchu. Aktualni problemy pravoznavstva, 1(9), 91-94.

Hlotov, M. Yak zakhystyty svoi hroshi na karttsi. Internet-vydannia «Ukrainska pravda». URL: https://www.epravda.com.ua/columns/2015/07/8/549843/ (data zvernennya: 04.01.2021). 
Yermolenko, 0. (ukl.). (2012). Velykyi tlumachnyi slovnyk suchasnoi ukrainskoi movy. Donetsk: TOV «Hloriia Treid».

\section{R. Kolb, Postgraduate student of Volyn National University named after Lesya Ukrainka \\ ORCID: 0000-0003-0187-3391}

\section{On the role and place of the national bank of Ukraine in the system of subjects of prevention of criminal offenses}

This scientific article clarifies the essence and socio-legal nature of the National Bank of Ukraine in the system of subjects of prevention of criminal offenses, as well as defines its role and developed scientifically based measures aimed at increasing the level of effectiveness of this activity.

As practice shows, one of the most socially dangerous criminal offenses committed in the field of economic activity are those that encroach on the established at the regulatory level of the banking institutions of Ukraine (such, in particular, include the following: Article 209 "Legalization (laundering) of proceeds from crime", Article 209-1 "Intentional violation of the law on prevention and counteraction to legalization (laundering) of proceeds from crime or terrorist financing"; Article 218-1 "Proof bank to insolvency "of the Criminal Code (Criminal Code) of Ukraine; etc.). Thus, since 2016, there has been a negative trend in Ukraine towards an annual increase in the number of criminal offenses registered in the Unified Register of Pre-trial Investigation (on average up to 500 cases), which take place in this area of public relations. these indicators have changed in subsequent years (2017-2020). Thus, according to the National Police, 4,263 cybercrimes were discovered in Ukraine in 2019 alone, including in the sphere of banking institutions, which caused losses of UAH 28 million.

The illegal activity of the bank is indicative in this context. Arcade, which illegally withdrew UAH 9 billion from its financial circulation, and reduced the ratio of the liquidity coverage ratio for all currencies (LCR) from $100 \%$ to $60.23 \%$. recognize that there is a complex applied problem that needs to be solved, including at the theoretical level. It should be noted that one of the conditions that contributes to the commission of criminal offenses in the field of banking institutions is the improper activities of the National Bank of Ukraine (NBU) to prevent them, as provided for in paragraph 30 of Part 1 of Art. 7 of the Law of Ukraine "On the National Bank of Ukraine".

Keywords: National Bank of Ukraine; warnings; criminal offense; the field of banking; financial fraud; harm caused; losses. 